УДК 595.789

DOI 10.52575/2658-3453-2021-3-3-255-269

\title{
Пустынные и полупустынные виды чешуекрылых (Lepidoptera) Нарынской долины (Внутренний Тянь-Шань, Киргизия)
}

\author{
С.К. Корб \\ Русское энтомологическое общество, Нижегородское отделение, \\ Россия, 603009, г. Нижний Новгород, а/я 97 \\ E-mail: stanislavkorb@list.ru
}

\begin{abstract}
Аннотация. Роль центров видообразования горной Средней Азии в формировании современной фауны насекомых региона отмечалась неоднократно, тем не менее фауна чешуекрылых внутренних областей Тянь-Шаня до сих пор остается слабо изученной. В связи с этим авторами рассмотрены пустынные и полупустынные элементы фауны чешуекрылых, обнаруженные экспедициями 2009-2019 гг. на территории Нарынской долины. Всего исследовано свыше 10 тыс. экземпляров. В результате исследования обнаружено 33 пустынных и полупустынных вида из 8 семейств чешуекрылых. Экземпляры отдельных видов не имеют морфологических отличий от бабочек, собранных в Ферганской долине и прилегающих пустынных районах Узбекистана и Казахстана. Все отмеченные в регионе пустынные виды присутствуют на территории Нарынской долины. Находки таких видов доказывают существующую прямую связь среднегорной Нарынской долины с предгорными пустынями Западного Тянь-Шаня и прилегающей Ферганской долины. Результаты исследования вносят вклад в изучение биоразнообразия Внутреннего Тянь-Шаня.
\end{abstract}

Ключевые слова: чешуекрылые, бабочки, пустынные виды, полупустынные виды, Киргизия.

Для цитирования: Корб С.К. 2021. Пустынные и полупустынные виды чешуекрылых (Lepidoptera) Нарынской долины (Внутренний Тянь-Шань, Киргизия). Полевой журнал биолога, 3 (3): 255-269. DOI: 10.52575/2658-3453-2021-3-3-255-269

Поступила в редакичию 30 июня 2021 года

\section{Desert and Semi-desert Species of Lepidoptera of Naryn Valley (Inner Tien Shan, Kyrgyzstan)}

\author{
Stanislav K. Korb \\ Russian Entomological Society, Nizhny Novgorod Division, \\ P.O. Box 97, Nizhny Novgorod, 603009, Russia \\ E-mail: stanislavkorb@list.ru
}

\begin{abstract}
The speciation centers value within the mountainous Middle Asia insects fauna origin was noted several times, but the Lepidoptera fauna of Inner Tian-Shan remain still poorly studied. Thus the author researched desert and semidesert elements in the Lepidoptera fauna recorded in 2009-2019 on the territory of Naryn valley. Over 10000 specimens have been studied. The specimens of these species have no morphological differences from the ones collected in Ferghana valley and adjacent areas of Uzbekistan and Kazakhstan. All recorded in the region species are detected in Naryn valley. These species records are evidences of the direct linkage between Naryn valley and foothills of West Tian-Shan and neighboring Ferghana valley. Results of this study adding new data into knowledge of the Inner TianShanian biodiversity.
\end{abstract}

Keywords: Lepidoptera, butterflies, desert species, semi-desert species, Kyrgyzstan. 
For citation: Korb S.K. 2021. Desert and Semi-desert Species of Lepidoptera of Naryn Valley (Inner Tien Shan, Kyrgyzstan). Field Biologist Journal, 3 (3): 255-269 (in Russian). DOI: $10.52575 / 2658-3453-2021-3-3-255-269$

\section{Введение}

Роль центров видообразования горной Средней Азии в формировании современной фауны насекомых региона отмечалась неоднократно [Groum-Grshimaïlo, 1890; Крыжановский, 1965; Лопатин, 1993]. Грумм-Гржимайло предположил наличие на Памире крупного центра видообразования бабочек и опубликовал первую реконструкцию возможного происхождения современных элементов фауны этого региона «Хронологическая таблица изменений конфигурации и рельефа Памиро-Тибета и прилегающих регионов с конца мелового периода до наших дней в соответствии с миграциями древних видов животных с Памира на восток и запад» [Groum-Grshimaïlo, 1890]. Это была первая попытка выяснения фауногенеза чешуекрылых Средней Азии и одна из первых реконструкций, в основе которой были взаимоотношения между автохтонными и аллохтонными элементами фауны.

Идеи Грумм-Гржимайло получили развитие в трудах О.Л. Крыжановского [1965], И.К. Лопатина [1993], Г.М. Абдурахманова и М.В. Набоженко [2016], Ю.Ю. Щеткина [2017]; они были в значительной степени использованы автором настоящего исследования для реконструирования фауногенеза и частично формогенеза (процесса образования локальных форм, который, в свою очередь, может (но не обязательно должен) привести к видообразованию; такой процесс наиболее характерен для «островных» фаун (включая горные)) булавоусых чешуекрылых Средней Азии [Корб, 1997; Korb, 2005].

Доказать те или иные этапы фауногенеза зачастую очень трудно. До начала текущего столетия в качестве доказательной базы использовались главным образом морфологические связи видов с их предполагаемыми предками либо морфологические ряды от наиболее примитивных к наиболее прогрессивным видам. Верифицировать основанные на таком анализе выводы обычно не представляется возможным, так как фоссилии чешуекрылых крайне малочисленны [Козлов, 1987].

Ситуация заметно изменилась после того, как для фауногенетических и формогенетических реконструкций начали использовать анализ отдельных последовательностей ДНК. Появились работы, основанные на таком анализе, посвященные как филогеографии отдельных видов чешуекрылых [Todisco et al., 2010; Nakatani et al., 2012; Korb et al., 2016], так и вопросам происхождения целых фаун [Arif, Khan, 2009; Johnsen et al., 2010; Dincă et al., 2011]. Несмотря на это, анализ современного распространения животных остается одним из основных инструментов выяснения фауногенеза [Крыжановский, 1965].

В настоящей работе рассмотрены пустынные и полупустынные элементы фауны чешуекрылых, обнаруженные нашими экспедициями 2009-2019 гг. на территории Нарынской долины (долина р. Нарын с окружающими ее горными хребтами [Корб, 1997, 2015a]). Пустынные и полупустынные виды животных - это такие виды, которые обитают в группе биотопов равнинных пустынь и полупустынь. Как правило, широко распространены в поясе пустынь. Не являются характерными для интразональных участков опустынивания горных территорий. Находки таких видов доказывают существующую прямую связь среднегорной Нарынской долины с предгорными пустынями Западного Тянь-Шаня и прилегающей Ферганской долины. 


\section{Материалы и методы исследования}

Материал для настоящего исследования собран в ходе экспедиций 2009-2019 гг. Были исследованы следующие местонахождения на территории Нарынской долины: 1) окр. г. Нарын $\left(41^{\circ} 25^{\prime} 32^{\prime \prime}\right.$ с. ш., 7559'51” в. д., 2000 м; обследованные высоты: 2000-

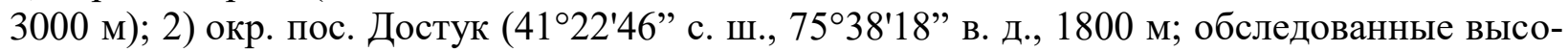
ты: 1800-2000 м); 3) окр. д. Куланак (41²1'21” с. ш., 75³0'13” в. д., 1800 м; обследованные высоты: 1800-2400 м); 4) окр. пос. Ак-Тал (41²4'26” с. ш., 75³'43” в. д., 1700 м; обследованные высоты: 1650-1750 м); 5) окр. пос. Баетово (4116'1” с. ш., 7456'50” в. д., 2000 м; обследованные высоты: 1800-3000 м); 6) окр. д. Ак-Кыя (41²7'15” с. ш., 7459'51” в. д., 1700 м; обследованные высоты: 1700-2200 м); 7) перевал Коро-Гоо (41³1'34” с. ш., 7442'37” в. д., 2761 м; обследованные высоты: 2400-2741 м); 8) берег р. Кара-Суу (4141’11” с. ш., 7258’31” в. д., 1231 м; обследованные высоты: 1200-1700 м).

Район исследования представляет собой среднегорную долину по берегам p. Нарын, а также прилегающие к ней бэдленды (Нарынский адыр). Основные биотопы: степи различных типов (главным образом разнотравные и ковыльные). Пустынные биотопы встречаются как интразональные, главным образом, в неугодьях.

Обрабатывались следующие группы чешуекрылых: Pyraloidea (Pyralidae, Crambidae), Noctuoidea (Erebidae, Noctuidae, Notodontidae, Nolidae, Arctiidae), Rhopalocera (Papilionidae, Pieridae, Satyridae, Nymphalidae, Lycaenidae, Hesperiidae). Всего исследовано свыше 10 тыс. экземпляров. Пустынные и полупустынные виды отмечены в 8 семействах, указанных далее в списке.

Материал определялся с помощью следующих руководств: Pyraloidea [Błeszyński, 1965; Roesler, 1973], Erebidae [Pekarsky et al., 2019; Ronkay et al., 2014]. Noctuidae [Behounek et al., 2010; Ronkay et al., 2008, 2011, 2017; Ronkay, Ronkay, 2009; Varga et al., 2013, 2015, 2020; Zilli et al., 2009], Nolidae [Leraut, 2020], Rhopalocera [Корб, 2015б]. В сложных случаях определение производилось специалистами по соответствующим группам.

\section{Результаты исследования}

Ниже приводится список пустынных и полупустынных видов огневкообразных, совкообразных и булавоусых чешуекрылых, обнаруженных в ходе наших исследований. Собранные в Нарынской долине экземпляры отдельных видов не имеют морфологических отличий от бабочек, собранных в Ферганской долине и прилегающих пустынных районах Узбекистана и Казахстана.

Список пустынных и полупустынных видов бабочек, отмеченных в Нарынской долине в 2009-2019 гг.

\section{Надсемейство Pyraloidea \\ Семейство Pyralidae}

Neopristocerella deltagrammella (Ragonot, 1888)

Материал: 3 §, 10.07.2014, Коро-Гоо; 1 ㅇ, со 2.07.2019 по 8.07.2019, Коро-Гоо.

Сбор осуществлялся на свет в кобрезиево-полынной полупустыне.

Пустынный вид, описанный из Туркмении (окрестности Ахал-Текке) [Ragonot, 1888]; в настоящее время известен из Турции (Карс), Азербайджана, Южной России (Дагестан), Юго-Восточного Казахстана, Туркмении [Slamka, 2019] и хр. Молдо-Тоо в Киргизии.

Pseudophycita deformella (Möschler, 1866)

Материал: 5 đ, 10.07.2014, с 24.07 2017 по 26.07.2017, с 10.07 2018 по 16.07.2018, Коро-Гоо; 1 §ै, 11.07.2014, Ак-Кыя.

Сбор осуществлялся на свет в кобрезиево-полынной полупустыне. 
Широко распространенный в степном, полупустынном и пустынном поясах Евразии (до Монголии) вид, населяющий различные аридные биотопы - в основном выровненные малотравные или низкотравные степи и полупустыни [Slamka, 2019].

Gymnancyla turensis (Ragonot, 1887)

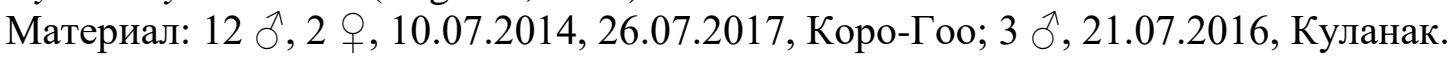

Сбор осуществлялся на свет в различных сухих биотопах: низкотравных злаковых степях, кобрезиево-полынных и кобрезиево-злаковых полупустынях, на сухих каменистых склонах.

Широко распространенный обитатель пустынного и полупустынного поясов Евразии и Северной Африки [Leraut, 2014]; встречается от Армении до Северо-Западного Китая.

Psorosa majorella Roesler, 1970

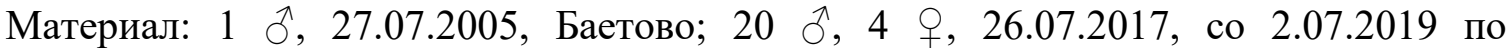
8.07.2019, Коро-Гоо.

Сбор осуществлялся на свет в кобрезиевой полупустыне на глинистых почвах (Коро-Гоо) и в редкотравной низкотравной степи (Баетово).

Вид описан из степного пояса Монголии (Центральный аймак, 26 км восточнее Сомон Лун). До недавнего времени отмечался из Монголии, Северо-Западного Китая и Южной России (Южный Урал, Алтай, Тува); в качестве биотопов указывались степи [Slamka, 2019].

Euzophera costivittella (Ragonot, 1887)

Материал: 4 क, 24.07.2019, Кара-Суу.

Сбор осуществлялся на свет в кобрезиево-полынной полупустыне.

Обитатель засушливых регионов Палеарктики (известен из: Южная Россия в районе Сарепты (ныне Волгоград), Иран, Западный Туркестан (Туркмения и Казахстан) и Афганистан [Agassiz, 2017].

Rhodophaeopsis shirazella Amsel, 1961

Материал: 30 స, 10 क, 10.07.2015, с 25.07.2017 по 26.07.2017, с 10.07.2018 по 16.07.2018, со 2.07.2019 по 8.07.2019, Коро-Гоо; 8 ठૈ, 24.07.2019, Кара-Суу.

Сбор осуществлялся на свет в кобрезиево-полынной полупустыне на каменистых почвах (Коро-Гоо) и в редкотравной степи на каменистых почвах (Кара-Суу). Вид, описанный из провинции Шираз в Иране. Типичный обитатель аридных стаций: низкотравных и редкотравных степей (в основном полынно-кобрезиевых и злаковых) и горных каменистых полупустынь.

Ancylosis fuscovenella (Ragonot, 1887)

Материал: 2 ๙ૈ, 26.07.2017, Коро-Гоо.

Сбор осуществлялся на свет в каменистой полупустыне с куртинами полыни.

Вид, описанный из окрестностей Кульджи в Северо-Западном Китае; ранее более ниоткуда не приводился.

A. samaritanella (Zeller, 1867)

Материал: 2 ○, 11.07.2014, Ак-Кыя.

Сбор осуществлялся на свет в кобрезиево-полынной полупустыне.

Локальный обитатель засушливых стаций Северной Африки, Испании, юга европейской части России и Среднего Востока [Leraut, 2014].

Vietteia terstrigella (Christoph, 1877)

Материал: 1 §, 21.07.2016, Куланак.

Сбор осуществлялся на свет на небольших песчаных дюнах вдоль переднего фронта Нарынского адыра.

Вид, описанный из пустынь Туркмении (Красноводск) и известный на настоящий момент из Южного Урала, Казахстана, Туркмении, Ирана и прилегающих стран [Leraut, 2014]. 


\section{Семейство Crambidae}

Euchromius scobiolae Błeszińsky, 1965

Материал: 1 §, 20.07.2016, Коро-Гоо.

Сбор осуществлялся на свет в кобрезиево-полынной полупустыне.

Вид, описан из пустынных районов Северного Афганистана в долине р. Кушка. До настоящего времени был известен по нескольким экземплярам, собранным в апреле в Афганистане (типовое местонахождение), Туркмении (Дорт-Кую, Сумбар) и Таджикистане (Курган-Тюбе) [Schouten, 1992]. Очевидно, летает как минимум в двух генерациях (первая ранней весной, вторая - летом).

Cybolomia fulvomixtalis Zerny, 1914

Материал: 1 ठૈ, 24.07.2019, Кара-Суу.

Сбор осуществлялся на свет в кобрезиево-полынной полупустыне.

Вид, описанный из окрестностей Кульджи в Северо-Западном Китае и известный до настоящего времени только из типового местонахождения.

Evergestis nomadalis (Lederer, 1871)

Материал: 1 ðૈ, с 25.07.2017 по 26.07.2017, Коро-Гоо.

Сбор осуществлялся на свет в кобрезиево-полынной полупустыне.

Широко распространенный в аридных районах Южной России, Греции, Турции, Ирана, Казахстана и Средней Азии вид [Alipanah et al., 2018].

Pyrausta pionalis Toll, 1948

Материал: 3 ○ૈ, 28.07.2017, с 10.07.2018 по 16.07.2018, Коро-Гоо.

Сбор осуществлялся на свет в кобрезиево-полынной полупустыне.

Вид, описанный из региона Гиркания в Иране. До недавнего времени приводился только из Ирана и Афганистана [Slamka, 2013].

\section{Надсемейство Noctuoidea \\ Семейство Nolidae}

Nycteola kuldzhana Obraztsov, 1953

Материал: 1 §, 13.07.2016, Кара-Суу.

Сбор осуществлялся на свет в кобрезиево-полынной полупустыне.

Широко распространенный в пустынях и полупустынях Средней Азии вид, на север доходящий до Южного Урала [Nupponen, Fibiger, 2012] и Волгограда [Anikin et al., 2017], на запад - до Украины [Геряк и др., 2014; Pekarsky, 2016], а на восток до Тувы.

\section{Семейство Erebidae}

Autophila eremochroa Boursin, 1940

Материал: 1 q, 16.07.2018, Коро-Гоо.

Сбор осуществлялся на свет в кобрезиево-полынной полупустыне.

Малоизвестный вид, описанный из «Центральной Азии», до недавнего времени отмеченный из предгорий Киргизского хр. и среднегорий Внутреннего Тянь-Шаня (хр. Джумгалтоо, Суусамыртоо) [Lehmann, Bergmann, 2005; Ronkay et al., 2014].

Eublemma griseola (Erschoff, 1874)

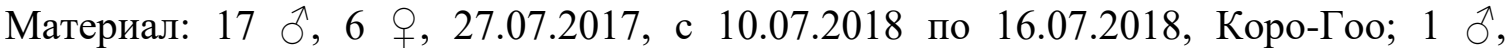
24.07.2019, Кара-Суу.

Сбор осуществлялся на свет в кобрезиево-полынной полупустыне, на сухих каменистых склонах с редкой куртинно-злаковой растительностью и в низкотравных степных стациях.

Широко распространенный в пустынной и полупустынной зонах вид, описанный из окрестностей Астрабада (Иран). В горах Киргизии поднимается до высоты 2000 м н.у.м., 
предпочитая сухие биотопы (главным образом низкогорные и среднегорные полупустыни, кобрезиевые и полынные сообщества) [Korb et al., 2016].

Odice arcuinna (Hübner, 1790)

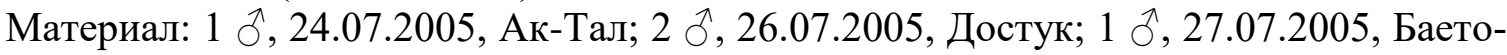

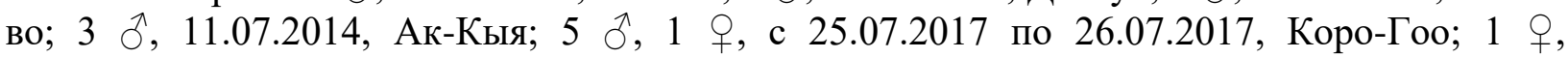
24.07.2019, Kapa-Суy.

Сбор осуществлялся на свет в кобрезиево-полынной полупустыне и на сухих каменистых склонах с редкой куртинно-злаковой растительностью.

Широко распространенный в аридных областях Средней Азии и Средиземноморья вид [Fibiger et al., 2010], в горах Средней Азии поднимается до высоты 2000 м н.у.м. [Korb et al., 2016].

Drasteria cailino (Lefèbvre, 1827)

Материал: 3 ○े, 2 , 24.07.2019, Кара-Суу.

Сбор осуществлялся на свет в низкогорной полынной глинистой полупустыне.

Широко распространенный в аридной зоне Евразии вид, встречается в пустынях, полупустынях и похожих стациях от Португалии до восточных пределов Центральной Азии [Matov, Korb, 2019].

Drasteria pseudopicta Matov et Korb, 2019

Материал: 1 ๙, Naryn (из колл. О. Иона, Зоологический Институт РАН).

Из Нарынской долины известен по единственному экземпляру, собранному в окрестностях города Нарын; биотоп неизвестен, однако можно предположить, что он был собран в типичных для окружающих Нарын глинистых полупустынных формациях с редкой полынно-злаковой растительностью.

Широко распространенный в пустынях и полупустынях Средней Азии, Казахстана и Южной России вид с вертикальным профилем до 2000 м н.у.м. [Matov, Korb, 2019].

\section{Семейство Noctuidae}

Tarachephia hueberi (Erschov, 1874)

Материал: 1 ð, 24.07.2017, Кара-Суу.

Сбор осуществлялся на свет в низкогорной полынной глинистой полупустыне.

Пустынный вид, собираемый обычно в малом числе [Weisert, 1997]; известен из Сирии, Ирака, Ирана, Заказказья, Узбекистана, Киргизии, Туркменистана и Афганистана [Kravchenko et al., 2004; Korb et al., 2016].

Dysmilichia bicyclica (Staudinger, 1888)

Материал: 6 กิ, 1 \%, 24.07.2019, Кара-Суу.

Сбор осуществлялся на свет в полынной глинистой полупустыне.

Широко распространенный в пустынях и полупустынях Средней Азии и Казахстана вид. По нашим наблюдениям, в Южном Казахстане (предгорья хр. Заилийский Алатау, хр. Богуты, хр. Сёгеты, горы Ак-Тау, горы Катутау, долины рр. Или и Чарын) предпочитает каменистые выровненные полупустыни с полынно-злаковой растительностью.

Shargacucullia xylophana (Boursin, 1934)

Материал: 1 ภ, 1 क, 10.07.2014, Коро-Гоо (Gen. prep. OP2885m, колл. О. Пекарского); 1 §, 24.07.2019, Кара-Суу.

Сбор осуществлялся на свет в каменистой редкотравной злаковой степи.

Предгорно-полупустынный вид, известный из Узбекистана, Казахстана, Киргизии, Таджикистана, долины р. Или в Синьцзян-Уйгурском округе Китая, Восточного Афганистана и Северо-Восточного Пакистана [Ronkay et al., 2011].

Cryphia distincta (Christoph, 1887)

Материал: 2 §, 24.07.2019, Кара-Суу.

Сбор осуществлялся на свет в каменистой редкотравной злаковой степи. 
Широко распространенный в полупустынных и степных стациях низкогорий и среднегорий Средней Азии и Казахстана от Джунгарии до Северного Ирана вид [Korb, 2020].

Hydredes yakobsoni Matov et Volynkin, 2014

Материал: 1 §, 24.07.2019, Кара-Суу.

Сбор осуществлялся на свет в полынной глинистой полупустыне.

Описанный недавно вид, ареал охватывает Юго-Восточный Казахстан (долина p. Чарын) и окрестности Токтогульского водохранилища (Киргизия) [Volynkin et al., 2014].

Cardepia helix Boursin, 1962

Материал: 18 ภ, 6 q, 11.07.2014, Ак-Кыя; 3 ภ, 21.07.2016, Куланак.

Сбор осуществлялся на свет в полынной глинистой полупустыне, а также в рудеральных биотопах.

Широко распространенный в Казахстане, Средней Азии и на Южной Украине пустынный и полупустынный вид [Hacker, 1998].

Dichagyris grisescens (Staudinger, 1878)

Материал: 3 §, 1 ๆ, 24.07.2019, Кара-Суу.

Сбор осуществлялся на свет в полынной глинистой полупустыне.

Широко распространенный в пустынях и полупустынях Туркмении, Узбекистана, Ирана, Казахстана и, возможно, Западного Таджикистана вид [Kozhantshikov, 1930].

D. leucomelas Brandt, 1941

Материал: 6 ô, 1 9, 24.07.2019, Кара-Суу.

Сбор осуществлялся на свет в полынной глинистой полупустыне.

Широко распространенный в пустынях и полупустынях Евразии вид, отмечен от Южной России на севере [Poltavsky, Nekrasov, 2002] до Иордании на юге [Kravchenko et al., 2015].

\section{Семейство Hesperiidae}

Eogenes alcides (Herrich-Schäffer, [1852])

Материал: 1 §, 24.07.2019, Кара-Суу.

Сбор осуществлялся в кобрезиево-полынной глинистой полупустыне.

Широко распространенный в пустынном и полупустынном поясах вид, населяющий сухие и остепненные луга, аридные предгорья, полупустыни, склоны с ксерофильной растительностью от Закавказья до Северо-Западного Китая [Tshikolovets, Nekrutenko, 2012].

\section{Семейство Satyridae}

Hyponephele naricina (Staudinger, 1870)

Материал: 1 ๙, 13.07.2004, Достук (каньон Кок-Жерты); 1 §,, 1 q, 13.07.2004, Куланак; 1 ๙, 14.07.2004, Ак-Тал; 1 ठૈ, 12.07.2004, Нарын.

Сбор осуществлялся на песчаных промоинах в подножии глинистых и супесчаных горок, формирующих передний фронт Нарынского адыра.

Широко распространенный в пустынях и полупустынях Казахстана, Туркмении, Узбекистана, Кыргызстана и Северо-Западного Китая вид. Биотопы: практически любые пустынные и полупустынные стации на песчаных и глинистых почвах.

Tomares fedtschenkoi (Erschoff, 1874)

\section{Семейство Lycaenidae}

Материал: 2 §, 20.04.2019, Кара-Суу.

Сбор осуществлялся в кобрезиево-полынной глинистой полупустыне во время цветения эфемероидов. 
Широко распространенный в пустынях и полупустынных предгорьях Казахстана, Туркмении, Узбекистана, Кыргызстана, Таджикистана и Афганистана локальный вид. Предпочитает сухие луговины и остепнения, овраги и балки.

Cupido prosecusa (Erschoff, 1874)

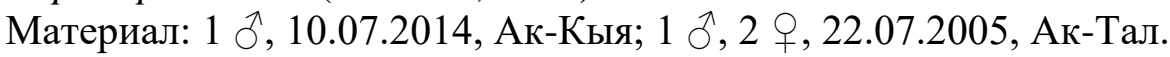

Сбор осуществлялся в низкотравных степных формациях вблизи зарослей кустарников.

Широко распространенный в пустынном поясе Евразии от Западного Казахстана до Центрального Китая вид. Занимает в основном полупустынные стации с зарослями Sphaerophysa salsula Pall. и Halimodendron halodendron Pall., которые являются его кормовыми растениями [Жданко, 2004]. На территории Киргизии, кроме Нарынской долины, отмечен в Иссык-Кульском рефугиуме [Lukhtanov, Lukhtanov, 1994].

Plebejus maracandicus (Erschoff, 1874)

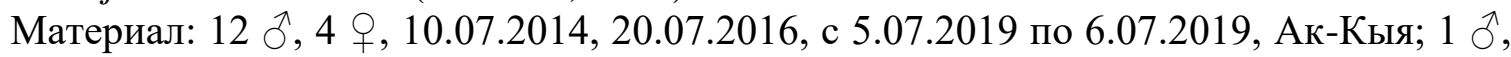
1 q, Naryn (без даты; из колл. Зоологического музея университета Гумбольдта в Берлине, Германия); 2 ๙ै, 1 क , 24.07.2019, Кара-Суу.

Из Нарынской долины долгое время был известен только по двум экземплярам с этикеткой "Naryn", хранящимся в коллекции Штаудингера (Зоологический музей университета Гумбольдта, Берлин). Поиски в непосредственной близости от города к обнаружению популяций вида не привели. Вид был обнаружен в Нарынской долине значительно западнее; скорее всего, граница распространения вида в долине р. Нарын проходит по зоне впадения в р. Нарын, р. Кок-Жерты и р. Ат-Баши. Биотопы сборов: сухие каменистые склоны с редкотравьем, низкотравные степи и кобрезиево-полынные полупустынные формации.

Полупустынный и степной вид, на север доходящий до Нижегородской и Ростовской областей России [Корб, 2012; Stradomsky, Arzanov, 2003].

Polyommatus elvira (Eversmann, 1854)

Материал: 2 §, 22.06.2018, Ак-Кыя; 1 §, 20.06.2016, Куланак.

Сбор осуществлялся на сухих каменистых склонах с куртинным редкотравьем и в низкотравных степях.

Распространенный в пустынях и полупустынях Казахстана, Туркменистана, Узбекистана, Таджикистана, Монголии, Кыргызстана и, возможно, Северо-Западного Китая, вид [Tshikolovets, 2005; Churkin, Kolesnichenko, 2019]. Населяет аридные и остепненные стации, тугаи, рудеральные биотопы.

\section{Выводы}

За 10 лет наших исследований на территории Нарынской долины обнаружено 33 пустынных и полупустынных вида из 8 семейств чешуекрылых.

Состав фауны огневкообразных чешуекрылых Внутреннего Тянь-Шаня не изучен. Согласно нашим сборам (с 1999 по 2019 гг., неопубликованные данные), во Внутреннем Тянь-Шане присутствует 130 видов надсемейства Pyraloidea, из которых семейство Pyralidae представлено 65 видами и семейство Crambidae - 55. Доля пустынных элементов в видовом составе огневкообразных чешуекрылых составляет 10,8 \%, из них по семействам: Pyralidae - 15,1 \% (9 видов) и Crambidae - 7,3 \% (4 вида).

Видовой состав булавоусых чешуекрылых Внутреннего Тянь-Шаня изучен [Корб, 2015б], на основании этих исследований можно сделать вывод о доле пустынных элементов в составе каждого семейства. Из 13 видов Hesperiidae, отмеченных на территории Внутреннего Тянь-Шаня, пустынным является один вид $(7,7 \%$ фауны семейства), из 51 вида Satyridae - также один вид является пустынным (2,0\%) и из 62 видов Lycaenidae - 
4 вида являются пустынными (6,4 \%). Всего среди надсемейства Rhopalocera 6 видов являются пустынными (4,8 \%).

В фауне совкообразных чешуекрылых Внутреннего Тянь-Шаня известно 342 вида: Nolidae - 2 вида, Erebidae - 51 вид, и Noctuidae - 289 видов [Korb et al., 2016]. Доля пустынных элементов среди надсемейства составляет $4,1 \%$, из них по семействам: Erebidae - 5 видов $(9,8 \%)$, Noctuidae -8 видов $(2,8 \%)$, Nolidae -1 вид $(50,0 \%$ - однако эта цифра явно завышена, так как фауна семейства в этом районе еще малоизучена и, скорее всего, значительно богаче, чем известно на текущий момент).

Все отмеченные в регионе пустынные виды присутствуют на территории Нарынской долины.

$\begin{array}{cccc}\text { Автор } & \text { выражает } & \text { глубочайшую } & \text { признательность } \\ \text { Ю.Б. Косареву } & \text { (2. Нижний } & \text { Новгород), } & \text { А.А. Шапошникову }\end{array}$ (г. Подольск Московской обл.), П.В. Егорову (г. Aлматы, Казахстан), А.Н. Самусю (2. Волгоград), А.Г. Белику (2.Саратов), Е.В. и О.П. Комаровым (г. Волгоград) за предоставление материала для обработки и участие в экспедиционной работе вместе $c$ автором. Особую благодарность автор выражает А.В. Свиридову (Зоологический музей МГУ, г. Москва), С.Ю. Синеву и А.Л. Львовскому (ЗИН РАН, г. С.-Петербург), А.Г. Татаринову (Институт биологии Коми НЦ УрО РАН, г. Сыктывкар), В. Маю (Dr. W.Mey (Museum für Naturkunde, Берлин, Германия)), Д. Лафонтену (Dr.J. Lafontaine (Canadian National Collection of Insects, Arachnids and Nematodes, Оттава, Канада)), Л. Кайле и Я. Куллбергу (Dr. L. Kaila and Dr J. Kullberg (Finnish Museum of Natural History, Хельсинки, Финляндия)) за предоставление доступа к курируемым ими коллекциям.

За помощь в определении материала автор признателен С.Ю. Синеву и А.Ю. Матову (ЗИН РАН, г. С.-Петербург), а также О. Пекарскому (Mr.O. Pekarsky, Будапешт, Венгрия).

\section{Список литературы}

1. Абдурахманов Г.М., Набоженко М.В. 2016. О фауногенезе жуков-чернотелок (Coleoptera: Tenebrionidae) Средней Азии. Юг России: экология, развитие, 11 (2): 170-177.

2. Жданко А.Б. 2004. Обзор голубянок рода Cupido Schrank, 1801 (Lepidoptera, Lycaenidae). Tethys Entomological Research, 10: 177-192.

3. Козлов М.В. 1987. Краткий обзор ископаемых находок булавоусых чешуекрылых. $B$ кн.: Булавоусые чешуекрылые СССР. Тезисы докладов к семинару «Систематика, фаунистика, экология, охрана булавоусых чешуекрылых» (г. Новосибирск, 2-5 октября 1987 г.). Новосибирск, Наука: 48-50.

4. Корб С.К. 1997. К познанию фауногенеза булавоусых чешуекрылых (Lepidoptera, Rhopalocera) Средней Азии. Зоологический журнал, 76 (9): 1046-1058.

5. Корб С.К. 2012. Plebejus maracandicus (Erschoff, 1874) - новый вид голубянок (Lepidoptera, Lycaenidae) для Верхнего Поволжья. Энтомологические и паразитологические исследования в Поволжье, 10: 98-99.

6. Корб С.К. 2015а. Нарынский аридный рефугиум и его значение в генезисе фауны Внутреннего Тянь-Шаня (на примере булавоусых чешуекрылых) (Lepidoptera, Papilionoformes). Энтомологические и паразитологические исследования в Поволжье, 16: 16-27.

7. Корб С.К. 2015б. Булавоусые чешуекрылые Внутреннего Тянь-Шаня (Lepidoptera: Papilionoformes). Эверсманния, Отд. вып. 6: 1-84. 
8. Коршунов Ю.П., Горбунов П.Ю. 1995. Дневные бабочки азиатской части России. Екатеринбург, Изд-во Уральского университета, 202 с.

9. Крыжановский О.Л. 1965. Состав и происхождение наземной фауны Средней Азии. Л., Наука, 420 с.

10. Лопатин И.К. 1993. Генезис высокогорных энтомофаун Средней и Центральной Азии (на примере жуков-листоедов трибы Entomoscelini). B кн.: Энтомология в СССР: экология и фаунистика, небольшие отряды насекомых. Материалы 10 съезда Всесоюзного энтомологического общества. Ленинград, 11-15 сентября 1989 г. СПб., Наука: 39-40.

11. Щеткин Ю.Ю. 2017. Высотно-поясная дифференциация и зоогеография Памиро-Алая на примере фаун булавоусых чешуекрылых (Lepidoptera, Rhopalocera). Таганрог, Изд-во Таганрогского института им. А.П. Чехова, 455 с.

12. Геряк Ю.М., Жаков О.В., Костюк І.Ю., Сергієнко В.М. 2014. Еколого-фауністичний огляд нолід (Nolidae, Noctuoidea, Lepidoptera) фауни України. Вісник Національного науковоприродничого музею, 12: 71-99.

13. Кожанчиков И. 1930. Обзор рода Dichagyris Ld. (Lepidoptera, Noctuidae). Русское энтомологическое обозрение, 24: 1-30 (на нем.).

14. Agassiz D. 2017. The mystery of Euzophera costivittella Ragonot, 1887 (Lepidoptera: Pyralidae) in Britain. Entomologist's Gazette, 68: 57-59.

15. Anikin V.V., Sachkov S.A., Zolotuhin V.V. 2017. "Fauna Lepidopterologica VolgoUralensis": from P. Pallas to present days. Proceedings of the Museum Witt Munich, 7: 1-696.

16. Arif I.A., Khan H.A. 2009. Molecular markers for biodiversity analysis of wildlife animals: a brief review. Animal Biodiversity and Conservation, 32: 9-17.

17. Behounek G., Ronkay L., Ronkay G. 2010. The Witt Catalogue. A Taxonomic Atlas of the Eurasian and North African Noctuoidea. Vol. 4. Plusiinae II. Budapest, Heterocera Press, 276 p.

18. Błeszyński S. 1965. Microlepidoptera Palaearctica. Bd. 1. Crambinae. Wien, Verlag Georg Fromme \& Co, $553 \mathrm{~s}$.

19. Churkin S.V., Kolesnichenko K.A. 2019. A new subspecies of Glabroculus elvira (Eversmann, 1854) (Lepidoptera, Lycaenidae) from the Dzhungarian Gobi desert, Mongolia. Zootaxa, 4555 (4): 581-587. DOI: 10.11646/zootaxa.4555.4.9.

20. Dincă V., Zakharov E.V., Hebert P.D.N., Vila R. 2011. Complete DNA barcode reference library for a country's butterfly fauna reveals high performance for temperate Europe. Proceedings of the Royal Society B, 278: 347-355. DOI: 10.1098/rspb.2010.1089.

21. Fibiger M., Ronkay L., Yela J.L., Zilli A. 2010. Noctuidae Europaeae. V. 12. Rivulinae, Boletobiinae, Hypenodinae, Araeopterononae, Eublemminae, Hermeniinae, Hypeninae, Phytometrinae, Euteliinae, and Micronoctuidae. Sorø, Entomological Press, 451 p.

22. Groum-Grshimaïlo G. 1890. Le Pamir et sa faune Lépidoptérologique. Mémoires sur les Lépidoptères, 4: 1-575.

23. Hacker H. 1998. Revision der Gattung Hadula Staudinger, 1889 (=Discestra Hampson, 1905; =Aglossestra Hampson, 1905; =Cardiestra Boursin, 1963), Anartomorpha Alpéraky, 1892, Trichanarta Hampson, 1895, Anarta Ochsenheimer, 1816 und Cardepia Hampson, 1905) mit Beschreibung einer neuen Gattung Hadumorpha gen. n. (Lepidoptera, Noctuidae). Esperiana, 6: 577-843.

24. Johnsen A., Rindal E., Ericson P.G.P., Zuccon D., Kerr K.C.R., Stoeckle M.Y., Lifjeld J.T. 2010. DNA barcoding of Scandinavian birds reveals divergent lineages in trans-Atlantic species. Journal of Ornithology, 151: 565-578. DOI: 10.1007/s10336-009-0490-3.

25. Korb S.K. 2005. Genesis der Tagfalterfauna Bergmittelasiens: Analyse, Problemen, Rekonstruktion. Nizhny Novgorod, Nizhegorodskaya Radiolobarotorija, 163 p.

26. Korb S.K. 2020. A review of genera Cryphia Hübner, 1818 and Bryophila Treitschke, 1825 within the mountainous Central Asia: a case of too many poorly described species (Lepidoptera: Noctuidae). Zootaxa, 4859 (4): 545-595. DOI: 10.11646/zootaxa.4859.4.6.

27. Korb S.K., Fric Z.F., Bartonova A. 2016. Phylogeography of Koramius charltonius (Gray, 1853) (Lepidoptera: Papilionidae): a case of too many poorly circumscribed subspecies. Nota lepidopterological, 39 (2): 169-191. DOI: 10.3897/nl.39.7682.

28. Korb S., Matov A., Pliushch I., Klyuchko Z., Poltavsky A. 2016. The Noctuoid moths of Kyrgyzstan. Moscow, KMK Scientific Press, 230 p. 
29. Kravchenko V.D., Müller G., Orlova O.B., Seplyarskaya V.N. 2004. The Catocalinae (Lepidoptera: Noctuidae) of Israel. Russian Entomological Journal, 13: 175-186.

30. Kravchenko V.D., Mooser J., Ronkay L., Revay E.E., Speidel W., Witt T., Müller G.C. 2015. An annotated checklist of the Noctuoidea of Jordan with remarks on ecology, phenology and zoogeography. Part V: Noctuinae (Lepidoptera: Noctuidae). SHILAP Revista de Lepidopterologia, 43 (172): 517-523.

31. Lehmann L., Bergmann A. 2005. The Noctuidae of Kyrgyzstan. A systematic and distributional list (Lepidoptera, Heterocera). Eisenhüttenstadt, Forst. Lausitz, 99 p.

32. Leraut P. 2014. Moths of Europe. Vol. 4. Pyralids 2. Verrières-le-Buisson, N.A.P Editions, $441 \mathrm{p}$.

33. Leraut P. 2020. Moths of Europe. Vol. 5. Noctuidae (partim). Verrières-le-Buisson, N.A.P. Editions, $621 \mathrm{p}$.

34. Lukhtanov V.A., Lukhtanov A.G. 1994. Die Tagfalter Nordwestasiens (Lepidoptera: Diurna). Herbipoliana, 3: 1-440.

35. Matov A.Yu., Korb S.K. 2019. A revision of the genus Drasteria of Central Asia and Kazakhstan with special attention to the adjacent areas (Lepidoptera: Erebidae). Zootaxa, 4673: 1-104. DOI: 10.11646/zootaxa.4673.1.1.

36. Nakatani T., Usami S.-i., Itoh T. 2012. Phylogeography of the genus Erebia (Lepidoptera, Nymphalidae) in Bulgaria, inferred by mitochondrial DNA. Lepidoptera Science, 63 (1): 25-36.

37. Nupponen K., Fibiger M. 2012. Additions to the checklist of Bombycoidea and Noctuoidea of the Volgo-Ural region. Part II. (Lepidoptera: Lasiocampidae, Erebidae, Nolidae, Noctuidae). Nota lepidopterological, 35 (1): 33-50.

38. Pekarsky O. 2016. First record of Nycteola kuldzhana Obraztsov, 1953 (Lepidoptera: Nolidae: Chloephorinae: Sarrothripini) from Ukraine. Ukrainska Entomofaunistyka, 7 (4): 54.

39. Pekarsky O., Ronkay G., Ronkay L., Varga Z. 2019. The Witt Catalogue. A taxonomic atlas of the Eurasian and North African Noctuoidea. V. 10. Psaphidinae II - Erebidae II. Budapest, Heterocera Press, $300 \mathrm{p}$.

40. Poltavsky A.N., Nekrasov A.V. 2002. The Noctuid Moths of the South of Russia and the Northern Caucasus (Lepidoptera). Esperiana, 9: 21-27.

41. Ragonot E.-L. 1888. Nouveaux genres et espèces de Phycitidae \& Galleriidae. Paris, Imprimerie Grandremy et Henon, 52 p. DOI: 10.5962/bhl.title.117519.

42. Roesler U. 1973. Microlepidoptera Palaearctica. Bd. 4. Phycitinae. Wien, Verlag Georg Fromme \& Co, $752 \mathrm{p}$.

43. Ronkay G., Ronkay L. 2009. The Witt Catalogue. A Taxonomic Atlas of the Eurasian and North African Noctuoidea. Vol. 2. Cuculliinae I. Budapest, Heterocera Press, 365 p.

44. Ronkay L., Ronkay G., Behounek G. 2008. The Witt Catalogue. A Taxonomic Atlas of the Eurasian and North African Noctuoidea. Vol. 1. Plusiinae I. Budapest, Heterocera Press, 345 p.

45. Ronkay G., Ronkay L., Gyulai P. 2011. The Witt Catalogue. A Taxonomic Atlas of the Eurasian and North African Noctuoidea. Vol. 5. Cuculliinae II and Psaphidinae. Budapest, Heterocera Press, $380 \mathrm{p}$.

46. Ronkay L., Ronkay G., Gyulai P., Varga Z. 2014. The Witt Catalogue. A Taxonomic Atlas of the Eurasian and North African Noctuoidea. Vol. 7. Erebidae I. Budapest, Heterocera Press, 281 p.

47. Ronkay L., Ronkay G., Gyulai P., Varga Z. 2017. The Witt Catalogue. A Taxonomic Atlas of the Eurasian and North African Noctuoidea. Vol. 9. Xyleninae I. Budapest, Heterocera Press, 342 p.

48. Schouten R.T.A. 1992. Revision of the genera Euchromius Guenée and Miyakea Marumo (Lepidoptera: Crambidae: Crambinae). Tijdschrift voor Entomologie, 135: 191-274.

49. Slamka F. 2013. Pyraloidea (Lepidoptera) of Europe. Vol. 3. Pyraustinae \& Spilomelinae. Bratislava, F. Slamka Edit, 357 p.

50. Slamka F. 2019. Pyraloidea (Lepidoptera) of Europe. Vol. 4. Phycitinae. Part I. Bratislava, F. Slamka Edit, 432 p.

51. Stradomsky B.V., Arzanov Yu.G. 2003. A new western subspecies of Plebeius maracandicus Erschoff, 1874 (Lepidoptera, Lycaenidae) from the Lower Don river. Caucasian Entomological Bulletin, 2: 195-196. 
52. Todisco V., Gratton P., Cesaroni D., Sbordoni V. 2010. Phylogeography of Parnassius apollo: hints on taxonomy and conservation of a vulnerable glacial butterfly invader. Biological Journal of the Linnean Society, 101: 169-183. DOI: 10.1111/j.1095-8312.2010.01476.x.

53. Tshikolovets V.V. 2005. The butterflies of Kyrgyzstan. Pardubice, Tshikolovets Publications, $512 \mathrm{p}$.

54. Tshikolovets V.V., Nekrutenko Y.P. 2012. The butterflies of Caucasus and Transcaucasia (Armenia, Azerbaijan, Georgia and Russian Federation). Pardubice, Tshikolovets Publications, 423 p.

55. Varga Z., Gyulai P., Ronkay L., Ronkay G. 2013. The Witt Catalogue. A taxonomic atlas of the Eurasian and North African Noctuoidea. Vol. 6. Noctuinae I. Budapest, Heterocera Press, 313 p.

56. Varga Z., Ronkay G., Ronkay L., Gyulai P. 2015. The Witt Catalogue. A taxonomic atlas of the Eurasian and North African Noctuoidea. Vol. 8. Noctuinae II. Budapest, Heterocera Press, 362 p.

57. Varga Z., Ronkay G., Gyulai P., Kiss Á., Ronkay L. 2020. The Witt Catalogue. A taxonomic atlas of the Eurasian and North African Noctuoidea. Vol. 11. Noctuinae III. Budapest, Heterocera Press, $313 \mathrm{p}$.

58. Volynkin A.V., Matov A.Yu., Gyulai P., Behounek G. 2014. A revision of the genus Protarchanara Beck, 1999 with description of a new genus and three new species (Lepidoptera, Noctuidae, Xyleninae). Zootaxa, 3755 (2): 165-178. DOI: 10.11646/zootaxa.3755.2.3.

59. Weisert F. 1997. Österreichische Turkmenistan-Expedition 1993 und 1996. Beitrag zur Lepidopterenfauna Zentralasiens (1. Teil). Zeitschrift der Arbeitsgemeinschaft Österreichischer Entomologen, 49: 65-75.

60. Zilli A., Varga Z., Ronkay G., Ronkay L. 2009. The Witt Catalogue. A taxonomic atlas of the Eurasian and North African Noctuoidea. Vol. 3. Apameini I. Budapest, Heterocera Press, 393 p.

\section{References}

1. Abdurakhmanov G.M., Nabozhenko M.V. 2016. On the faunagenesis of Tenebrionidae (Coleoptera) of Middle Asia. South of Russia: ecology, development, 11 (2): 170-177 (in Russian).

2. Zhdanko A.B. 2004. A review of the genus Cupido Schrank, 1801 (Lepidoptera, Lycaenidae). Tethys Entomological Research, 10: 177-192 (in Russian).

3. Kozlov M.V. 1987. Kratkiy obzor iskopayemykh nakhodok bulavousykh cheshuyekrylykh [Short review of the butterfly fossils]. In: Bulavousyye cheshuyekrylyye SSSR [Butterflies of USSR]. Theses of reports to the meeting "Systematics, faunistics, ecology, conservation of butterflies" (Novosibirsk, October 2-5, 1987). Novosibirsk, Publ. Nauka: 48-50.

4. Korb S.K. 1997. To the knowledge of faunagenesis of butterflies (Lepidoptera, Rhopalocera) of Middle Asia. Zoological Journal, 76 (9): 1046-1058 (in Russian).

5. Korb S.K. 2012. Plebejus maracandicus (Erschoff, 1874) - new blue butterfly species (Lepidoptera, Lycaenidae) from Upper Volga Region. Entomological and Parasitological Studies in Volga Region, 10: 98-99 (in Russian).

6. Korb S.K. 2015a. Naryn arid rephugium and its value in the genesis of fauna of Inner TianShan (on example of the butterflies) (Lepidoptera, Papilionoformes). Entomological and Parasitological Studies in Volga Region, 16: 16-27 (in Russian).

7. Korb S.K. 2015b. Butterflies of Inner Tian-Shan (Lepidoptera: Papilionoformes). Eversmannia, Suppl. 6: 1-84 (in Russian).

8. Korshunov Yu.P., Gorbunov P.Yu. 1995. Dnevnyye babochki aziatskoy chasti Rossii [Butterflies of the Asiatic part of Russia]. Yekaterinburg, Ural University Publishing House, 202 p.

9. Kryzhanovskiy O.L. 1965. Sostav i proiskhozhdeniye nazemnoy fauny Sredney Azii [Composition and origin of the terrestrial fauna of Middle Asia]. Leningrad. Publ. Nauka, 420 p.

10. Lopatin I.K. 1993. Genezis vysokogornykh entomofaun Sredney i Tsentral'noy Azii (na primere zhukov-listoyedov triby Entomoscelini) [Genesis of the high-mountainous entomofaunas within Middle and Central Asia (on example of tribus Entomoscelini)]. In: Entomologiya v SSSR: ekologiya i faunistika, nebol'shiye otryady nasekomykh [Entomology in USSR: ecology and faunistics, small Insecta orders]. Materials of the 10th Congress of the All-Union Entomological Society (Leningrad, September 11-15, 1989). Saint-Petersburg, Publ. Nauka: 39-40. 
11. Shchetkin Yu.Yu. 2017. Vertical differentiation and zoogeography of Pamir-Alai on example of butterfly faunas (Lepidoptera, Rhopalocera). Taganrog, Taganrog University Publishing House, 455 p. (in Russian).

12. Geryak Y.M., Zhakov O.V., Kostjuk I.Y., Sergienko V.M. 2014. Ecologic Faunistic review of Nolidae (Noctuoidea, Lepidoptera) of Ukraine. Proceedings of the National Museum of Natural Histori, 12: 71-99 (in Ukrainian).

13. Kozhantshikov I. 1930. Uebersicht der Gattung Dichagyris Ld. (Lepidoptera, Noctuidae). [Review of the genus Dichagyris Ld. (Lepidoptera, Noctuidae)]. Revue Russe D'Entoiologie, 24: 1-30 (in German).

14. Agassiz D. 2017. The mystery of Euzophera costivittella Ragonot, 1887 (Lepidoptera: Pyralidae) in Britain. Entomologist's Gazette, 68: 57-59.

15. Anikin V.V., Sachkov S.A., Zolotuhin V.V. 2017. "Fauna Lepidopterologica VolgoUralensis": from P. Pallas to present days. Proceedings of the Museum Witt Munich, 7: 1-696.

16. Arif I.A., Khan H.A. 2009. Molecular markers for biodiversity analysis of wildlife animals: a brief review. Animal Biodiversity and Conservation, 32: 9-17.

17. Behounek G., Ronkay L., Ronkay G. 2010. The Witt Catalogue. A Taxonomic Atlas of the Eurasian and North African Noctuoidea. Vol. 4. Plusiinae II. Budapest, Heterocera Press, 276 p.

18. Błeszyński S. 1965. Microlepidoptera Palaearctica. Bd. 1. Crambinae [Microlepidoptera Palaearctica. Vol. 1. Crambinae]. Wien, Verlag Georg Fromme \& Co, 553 p.

19. Churkin S.V., Kolesnichenko K.A. 2019. A new subspecies of Glabroculus elvira (Eversmann, 1854) (Lepidoptera, Lycaenidae) from the Dzhungarian Gobi desert, Mongolia. Zootaxa, 4555 (4): 581-587. DOI: 10.11646/zootaxa.4555.4.9.

20. Dincă V., Zakharov E.V., Hebert P.D.N., Vila R. 2011. Complete DNA barcode reference library for a country's butterfly fauna reveals high performance for temperate Europe. Proceedings of the Royal Society B, 278: 347-355. DOI: 10.1098/rspb.2010.1089.

21. Fibiger M., Ronkay L., Yela J.L., Zilli A. 2010. Noctuidae Europaeae. V. 12. Rivulinae, Boletobiinae, Hypenodinae, Araeopterononae, Eublemminae, Hermeniinae, Hypeninae, Phytometrinae, Euteliinae, and Micronoctuidae. Sorø, Entomological Press, 451 p.

22. Groum-Grshimaïlo G. 1890. Le Pamir et sa faune Lépidoptérologique [The Pamir and its Lepidopterological fauna]. Mémoires sur les Lépidoptères, 4: 1-575 (in French).

23. Hacker H. 1998. Revision der Gattung Hadula Staudinger, 1889 (=Discestra Hampson, 1905; =Aglossestra Hampson, 1905; =Cardiestra Boursin, 1963), Anartomorpha Alpéraky, 1892, Trichanarta Hampson, 1895, Anarta Ochsenheimer, 1816 und Cardepia Hampson, 1905) mit Beschreibung einer neuen Gattung Hadumorpha gen. n. (Lepidoptera, Noctuidae) [Revision of the genus Hadula Staudinger, 1889 (=Discestra Hampson, 1905; =Aglossestra Hampson, 1905; =Cardiestra Boursin, 1963), Anartomorpha Alpéraky, 1892, Trichanarta Hampson, 1895, Anarta Ochsenheimer, 1816 and Cardepia Hampson, 1905) with a description of one new genus Hadumorpha gen. n. (Lepidoptera, Noctuidae)]. Esperiana, 6: 577-843 (in German).

24. Johnsen A., Rindal E., Ericson P.G.P., Zuccon D., Kerr K.C.R., Stoeckle M.Y., Lifjeld J.T. 2010. DNA barcoding of Scandinavian birds reveals divergent lineages in trans-Atlantic species. Journal of Ornithology, 151: 565-578. DOI: 10.1007/s10336-009-0490-3.

25. Korb S.K. 2005. Genesis der Tagfalterfauna Bergmittelasiens: Analyse, Problemen, Rekonstruktion [Genesis of the butterfly fauna of Central Asia: analysis, problems, reconstruction]. Nizhny Novgorod, Nizhegorodskaya Radiolobarotorija, 163 p. (in German).

26. Korb S.K. 2020. A review of genera Cryphia Hübner, 1818 and Bryophila Treitschke, 1825 within the mountainous Central Asia: a case of too many poorly described species (Lepidoptera: Noctuidae). Zootaxa, 4859 (4): 545-595. DOI: 10.11646/zootaxa.4859.4.6.

27. Korb S.K., Fric Z.F., Bartonova A. 2016. Phylogeography of Koramius charltonius (Gray, 1853) (Lepidoptera: Papilionidae): a case of too many poorly circumscribed subspecies. Nota lepidopterological, 39 (2): 169-191. DOI: 10.3897/nl.39.7682.

28. Korb S., Matov A., Pliushch I., Klyuchko Z., Poltavsky A. 2016. The Noctuoid moths of Kyrgyzstan. Moscow, Publ. KMK Scientific Press, 230 p.

29. Kravchenko V.D., Müller G., Orlova O.B., Seplyarskaya V.N. 2004. The Catocalinae (Lepidoptera: Noctuidae) of Israel. Russian Entomological Journal, 13: 175-186. 
30. Kravchenko V.D., Mooser J., Ronkay L., Revay E.E., Speidel W., Witt T., Müller G.C. 2015. An annotated checklist of the Noctuoidea of Jordan with remarks on ecology, phenology and zoogeography. Part V: Noctuinae (Lepidoptera: Noctuidae). SHILAP Revista de Lepidopterologia, 43 (172): 517-523.

31. Lehmann L., Bergmann A. 2005. The Noctuidae of Kyrgyzstan. A systematic and distributional list (Lepidoptera, Heterocera). Eisenhüttenstadt, Publ. Forst. Lausitz, 99 p.

32. Leraut P. 2014. Moths of Europe. Vol. 4. Pyralids 2. Verrières-le-Buisson, N.A.P Editions, $441 \mathrm{p}$.

33. Leraut P. 2020. Moths of Europe. Vol. 5. Noctuidae (partim). Verrières-le-Buisson, N.A.P. Editions, $621 \mathrm{p}$.

34. Lukhtanov V.A., Lukhtanov A.G. 1994. Die Tagfalter Nordwestasiens (Lepidoptera: Diurna) [The butterflies of Northwest Asia (Lepidoptera: Diurna)]. Herbipoliana, 3: 1-440 (in German).

35. Matov A.Yu., Korb S.K. 2019. A revision of the genus Drasteria of Central Asia and Kazakhstan with special attention to the adjacent areas (Lepidoptera: Erebidae). Zootaxa, 4673: 1-104. DOI: 10.11646/zootaxa.4673.1.1.

36. Nakatani T., Usami S.-i., Itoh T. 2012. Phylogeography of the genus Erebia (Lepidoptera, Nymphalidae) in Bulgaria, inferred by mitochondrial DNA. Lepidoptera Science, 63 (1): 25-36.

37. Nupponen K., Fibiger M. 2012. Additions to the checklist of Bombycoidea and Noctuoidea of the Volgo-Ural region. Part II. (Lepidoptera: Lasiocampidae, Erebidae, Nolidae, Noctuidae). Nota lepidopterological, 35 (1): 33-50.

38. Pekarsky O. 2016. First record of Nycteola kuldzhana Obraztsov, 1953 (Lepidoptera: Nolidae: Chloephorinae: Sarrothripini) from Ukraine. Ukrainska Entomofaunistyka, 7 (4): 54 p.

39. Pekarsky O., Ronkay G., Ronkay L., Varga Z. 2019. The Witt Catalogue. A taxonomic atlas of the Eurasian and North African Noctuoidea. V. 10. Psaphidinae II - Erebidae II. Budapest, Publ. Heterocera Press, $300 \mathrm{p}$.

40. Poltavsky A.N., Nekrasov A.V. 2002. The Noctuid Moths of the South of Russia and the Northern Caucasus (Lepidoptera). Esperiana, 9: 21-27.

41. Ragonot E.-L. 1888. Nouveaux genres et espèces de Phycitidae \& Galleriidae [Nouveaux genres et espèces de Phycitidae \& Galleriidae]. Paris, Imprimerie Grandremy et Henon, 52 p. DOI: 10.5962/bhl.title.117519 (in French).

42. Roesler U. 1973. Microlepidoptera Palaearctica. Bd. 4. Phycitinae. Wien, Publ. Verlag Georg Fromme \& Co, 752 p.

43. Ronkay G., Ronkay L. 2009. The Witt Catalogue. A Taxonomic Atlas of the Eurasian and North African Noctuoidea. Vol. 2. Cuculliinae I. Budapest, Heterocera Press, 365 p.

44. Ronkay L., Ronkay G., Behounek G. 2008. The Witt Catalogue. A Taxonomic Atlas of the Eurasian and North African Noctuoidea. Vol. 1. Plusiinae I. Budapest, Heterocera Press, 345 p.

45. Ronkay G., Ronkay L., Gyulai P. 2011. The Witt Catalogue. A Taxonomic Atlas of the Eurasian and North African Noctuoidea. Vol. 5. Cuculliinae II and Psaphidinae. Budapest, Heterocera Press, $380 \mathrm{p}$.

46. Ronkay L., Ronkay G., Gyulai P., Varga Z. 2014. The Witt Catalogue. A Taxonomic Atlas of the Eurasian and North African Noctuoidea. Vol. 7. Erebidae I. Budapest, Heterocera Press, 281 p.

47. Ronkay L., Ronkay G., Gyulai P., Varga Z. 2017. The Witt Catalogue. A Taxonomic Atlas of the Eurasian and North African Noctuoidea. Vol. 9. Xyleninae I. Budapest, Heterocera Press, 342 p.

48. Schouten R.T.A. 1992. Revision of the genera Euchromius Guenée and Miyakea Marumo (Lepidoptera: Crambidae: Crambinae). Tijdschrift voor Entomologie, 135: 191-274.

49. Slamka F. 2013. Pyraloidea (Lepidoptera) of Europe. Vol. 3. Pyraustinae \& Spilomelinae. Bratislava, F. Slamka Edit, 357 p.

50. Slamka F. 2019. Pyraloidea (Lepidoptera) of Europe. Vol. 4. Phycitinae. Part I. Bratislava, F. Slamka Edit, 432 p.

51. Stradomsky B.V., Arzanov Yu.G. 2003. A new western subspecies of Plebeius maracandicus Erschoff, 1874 (Lepidoptera, Lycaenidae) from the Lower Don river. Caucasian Entomological Bulletin, 2: 195-196.

52. Todisco V., Gratton P., Cesaroni D., Sbordoni V. 2010. Phylogeography of Parnassius apollo: hints on taxonomy and conservation of a vulnerable glacial butterfly invader. Biological Journal of the Linnean Society, 101: 169-183. DOI: 10.1111/j.1095-8312.2010.01476.x. 
53. Tshikolovets V.V. 2005. The butterflies of Kyrgyzstan. Pardubice, Tshikolovets Publications, $512 \mathrm{p}$.

54. Tshikolovets V.V., Nekrutenko Y.P. 2012. The butterflies of Caucasus and Transcaucasia (Armenia, Azerbaijan, Georgia and Russian Federation). Pardubice, Tshikolovets Publications, $423 \mathrm{p}$.

55. Varga Z., Gyulai P., Ronkay L., Ronkay G. 2013. The Witt Catalogue. A taxonomic atlas of the Eurasian and North African Noctuoidea. Vol. 6. Noctuinae I. Budapest, Heterocera Press, 313 p.

56. Varga Z., Ronkay G., Ronkay L., Gyulai P. 2015. The Witt Catalogue. A taxonomic atlas of the Eurasian and North African Noctuoidea. Vol. 8. Noctuinae II. Budapest, Heterocera Press, 362 p.

57. Varga Z., Ronkay G., Gyulai P., Kiss Á., Ronkay L. 2020. The Witt Catalogue. A taxonomic atlas of the Eurasian and North African Noctuoidea. Vol. 11. Noctuinae III. Budapest, Heterocera Press, $313 \mathrm{p}$.

58. Volynkin A.V., Matov A.Yu., Gyulai P., Behounek G. 2014. A revision of the genus Protarchanara Beck, 1999 with description of a new genus and three new species (Lepidoptera, Noctuidae, Xyleninae). Zootaxa, 3755 (2): 165-178. DOI: 10.11646/zootaxa.3755.2.3.

59. Weisert F. 1997. Österreichische Turkmenistan-Expedition 1993 und 1996. Beitrag zur Lepidopterenfauna Zentralasiens (1. Teil) [Austrian Turkmenistan expedition 1993 and 1996. Contribution to the lepidopteran fauna of Central Asia (1st part)]. Zeitschrift der Arbeitsgemeinschaft Österreichischer Entomologen, 49: 65-75 (in German).

60. Zilli A., Varga Z., Ronkay G., Ronkay L. 2009. The Witt Catalogue. A taxonomic atlas of the Eurasian and North African Noctuoidea. Vol. 3. Apameini I. Budapest, Heterocera Press, 393 p.

\section{ИНФОРМАЦИЯ ОБ АВТОРЕ}

Корб Станислав Константинович, независимый исследователь, г. Бишкек, Киргизия

\section{INFORMATION ABOUT THE AUTHOR}

Korb Stanislav K., Independent Researcher, Bishkek, Kyrgyzstan 